\title{
LA ESCUELA DE LA AMISTAD O EL FILÓSOFO ENAMORADO EN LA PRENSA ESPAÑOLA DE LA ILUSTRACIÓN: REPOSICIONES TRAS LA MUERTE DE FORNER (1800-1834)
}

\author{
La Escuela de la Amistad o El Filósofo Enamorado \\ in the Spanish Press of Enlightenment: Revivals after \\ Forner's Death (1800-1834)
}

Jesús CAÑAS MURILLO

Universidad de Extremadura

jcanas@unex.es

Fecha de recepción: 16/11/2020

Fecha de aceptación definitiva: 20/07/2021

RESUMEN: En este artículo se estudia una de las producciones dramáticas de Juan Pablo Forner, su única pieza larga completa que hemos conservado en la actualidad, La escuela de la amistad o El Filósofo enamorado, estrenada, ante el gran público, en Madrid, en el Teatro de la Cruz, el miércoles 28 de enero de 1795. Se investiga sobre la repercusión que tuvo la puesta en escena de este texto en los años posteriores a la muerte de Forner, hasta los finales del reinado de Fernando VII en España, según quedó reflejado en las publicaciones periódicas del momento, la aceptación que recibió por parte del público que acudió a los locales teatrales y por los críticos que se ocuparon de ella, las recaudaciones de taquilla que obtuvo en las sesiones, la estructura de la función dramática en la que fue incluida, las compañías teatrales que se encargaron de los montajes, las reposiciones de las que fue objeto. Todo ello va a demostrar que El Filósofo enamorado fue una comedia de éxito, demandada por los espectadores, que acudieron con regularidad a los espectáculos en los que, en los teatros del periodo, le fue reservada una importante y esencial participación.

Palabras clave: historia literaria; siglo XVIII español; prensa; teatro; comedia neoclásica; El Filósofo enamorado; Juan Pablo Forner. 
ABSTRACT: This article studies one of the dramatic productions of Juan Pablo Forner, his only complete long play that we have preserved today, La escuela de la amistad o El Filósofo enamorado, (The School of Friendship or The Philosopher in Love), premiered, before the general public, in Madrid, at the Teatro de la Cruz, on Wednesday, January 28, 1795. Research is being made on the impact of the staging of this text in the years after Forner's death, until the end of Ferdinand VII's reign in Spain, as reflected in the Spanish press of the time, the acceptance it received from the public who attended the theatrical venues and by the critics who took care of it, the box office proceeds it obtained in the sessions, the structure of the dramatic performance in which it was included, the theatrical companies that were in charge of the montages, the revivals of which it was subjected. All this will prove that $E l$ Filosofo enamorado (The Philosopher in Love) was a successful comedy, demanded by the audience, who regularly attended the shows in which, in the theaters of the period, an important and essential participation was reserved for it.

Key words: literary history; spanish eighteenth century; press; theatre; neoclassical comedy; El Filósofo enamorado; Juan Pablo Forner.

\section{PREÁMBULO Y PRESENTACIÓN}

El reconocimiento de Juan Pablo Forner como intelectual, como pensador y como polemista de la Ilustración ha sido general, con mayor o menor intensidad, casi desde los orígenes de la historiografía y la crítica literarias españolas hasta la actualidad. Menos consenso ha habido en su buena aceptación como autor preocupado por el mundo de la farándula y como escritor dramático, y en la buena consideración de su producción encuadrada en este campo. Lo estudiamos en trabajos nuestros anteriores ${ }^{1}$. Sin embargo, nuestras investigaciones sobre dos de las obras cómicas compuestas por el emeritense, El Filósofo enamorado y Los aduladores, demostraron la buena acogida que llegaron a obtener, en sus auditorios, sus piezas que llegaron a ser montadas sobre los escenarios y ofrecidas, de tal modo, a los espectadores de los años ilustrados; así como el gran éxito que cosecharon entre las compañías de cómicos de aquel periodo, las cuales seleccionaron, sistemáticamente, algunas de sus creaciones para incluirlas como parte habitual de sus repertorios. Ante esos datos resultaba evidente que el teatro de Forner estaba falto de un nuevo estudio, de una nueva revisión, de una nueva consideración y enjuiciamiento, a la luz de nuevos datos que hoy podrían ser detectados y recopilados ${ }^{2}$.

1. Cf. de Cañas Murillo, Jesús. "Los aduladores, de Juan Pablo Forner, comedia olvidada». en Homenaje a José Checa. Madrid: CSIC, en prensa; y "Un texto teatral oculto de Juan Pablo Forner: La comedia de Los Aduladores", Lexis. Revista de Lingüística y Literatura, volumen XLIV, número 2 (diciembre de 2020), pp. 699-744.

2. En la actualidad, la profesora Piedad Bolaños Donoso y yo mismo trabajamos en un proyecto de investigación entre cuyos objetivos está localizar todos los escritos posibles sobre el mundo del teatro que se encuentran en la producción legada por Juan Pablo Forner a la posteridad y todas sus 
Conscientes de esta realidad, elaboramos, para intelectuales, eruditos, especialistas y curiosos lectores, un trabajo centrado en su única comedia de larga extensión que hemos conservado completa en nuestros días, La escuela de la amistad o El Filósofo enamorado. Indagamos sobre su repercusión en los periódicos españoles de la época, de sus puestas en escena dieciochescas en vida de Forner y sobre la acogida que recibió por parte de sus primeros receptores. El primer trabajo resultante de ello fue titulado "La Escuela de la Amistad o El Filo'sofo enamorado en la prensa española de la Ilustracio'n: Estrenos y reposiciones en vida de Forner (1790-1797)», y dio cuerpo a un artículo, que actualmente está en curso de publicación en la revista Annali. Sezione Romanza, editada por la Universidad de Nápoles L'Orientale.

En el presente trabajo vamos a continuar la presentación de los resultados obtenidos en aquella investigación. Vamos a demostrar que, tras la muerte del extremeño, El Filósofo enamorado siguió disfrutando del favor del público del momento, continuó manteniendo una presencia habitual en los repertorios de las compañías de cómicos, y en teatros de la última era ilustrada, entre 1800 y 1834, los años inmediatos a la guerra de la Independencia y los años en los que esta se desarrolló, y en los años en los que transcurrió el reinado en España de Fernando VII, el Deseado, monarca felón. Vamos a demostrar que el texto en todo momento gozó de buena reputación y aceptación por parte de los espectadores, que acudían en notable número a los locales en los que fue escenificada, proporcionándoles buenos beneficios en las recaudaciones. Pondremos así de manifiesto que la obra dramática de Juan Pablo Forner está necesitada de una nueva valoración, al igual que la figura, y la producción relacionada con el teatro, de su creador, que el emeritense debe ser incluido, sin dilación, entre los escritores teatrales principales, y de éxito, que desarrollaron y dieron a conocer su labor en los tiempos del siglo XVIII español y en los primeros años del siglo XIX.

\section{LAS REPOSICIONES DE EL FILÓSOFO EN EL PRIMER OCHOCIENTOS}

Varios fueron los montajes que recibió La escuela de la amistad o El Filósofo enamorado tras la muerte de Juan Pablo Forner, desde el año 1800 hasta el año 1834, en el que hemos cerrado nuestras indagaciones. Entre 1797, fecha en la que se produjo su fallecimiento, y 1800 no hemos localizado, en periódicos del momento, referencias a reposiciones de esa comedia en los escenarios públicos, a diferencia de lo que va a ocurrir en el primer ochocientos, en los años de la Ilustración que abarcan el final del reinado de Carlos IV, la invasión francesa de España

obras dramáticas originales que puedan ser localizadas. El material resultante de nuestras indagaciones sería editado críticamente y estudiado, con el fin de que den cuerpo a un libro que rescate de la historia, y ponga a disposición de los interesados lectores y de los especialistas actuales, esa aportación tan importante de la Ilustración española a la cultura de las épocas posteriores y a la nuestra propia. 
con la consiguiente guerra de la Independencia y la época en la que Fernando VII ciñó la corona en su país. En este periodo histórico, en la prensa española quedan registradas abundantes representaciones de El Filósofo enamorado, programadas en distintos momentos, en diversas ciudades y en diferentes locales teatrales accesibles a cualquier tipo de espectadores interesados, siempre y cuando puedan satisfacer los precios de las correspondientes entradas y así obtener acceso libre a la localidades disponibles. Lo comprobamos a continuación.

\subsection{Montajes en 1800}

El montaje de La escuela de la amistad del que da noticia el Diario de Madrid tuvo lugar en el mes de enero de 1800, casi inmediatamente después de celebrarse las fiestas de Navidad. El anunció del estreno se incluyó en el número correspondiente al miércoles 15 de enero de 1800, en su página 60:

DIARIO DE MADRID

DEL MIERCOLES 15 DE ENERO DE 1800.

(P. 60).

\section{Teatros.}

[...]. En el de la calle de la Cruz, por la Compañia del Sr. Luis Navarro, se representa la Comedia titulada: el Filosofo enamorado; de subida, con una buena tonadilla y un fin de fiesta; á las 4 1⁄2.2. La entrada de antes de ayer fue de 4906.

\section{CON PRIVILEGIO REAL.}

La compañía que se encargó de la puesta en escena fue la «del Sr. Luis Navarro", aunque no se incluyen aquí noticias sobre su composición para la temporada en curso.

El Filósofo enamorado sustituyó en las tablas del Teatro de la Cruz a una función integrada por la «Comedia heroica titulada: Palmis y Oronte, de teatro, con una buena tonadilla y un divertido fin de fiesta ${ }^{3}$. Estuvo siete días en cartel, entre el 15 y el 21 de enero de 1800, hasta que, el día 22 de enero, fue reemplazada por «la Comedia titulada: Sancho Ortiz de las Roelas, tragedia en 5 actos, tomada de Lope de Vega Carpio, y refundida por Don Candido Maria Trigueros, Bibliotecario que fué de San Isidro el Real, nueva, con una tonadilla y fin de fiesta, de teatro" ${ }^{4}$. Durante todos los días de montaje, el espectáculo tuvo su comienzo a las cuatro y media de la tarde, y su estructura, sistemáticamente, estuvo formado por, evidentemente, la pieza de Forner, acompañada de «una buena tonadilla y un fin de fiesta". No se especifica en los ejemplares de esas fechas la naturaleza del

3. Diario de Madrid, del martes 14 de enero de 1800, p. 56.

4. Diario de Madrid, del miércoles 22 de enero de 1800, p. 88. 
fin de fiesta, ni el título de la tonadilla elegida cada día, ni si estas obras fueron cambiadas en alguna de las jornadas en la que fue ofrecida a los espectadores la creación de Forner.

A través de los correspondientes números del Diario de Madrid, podemos conocer los beneficios diarios obtenidos por El Filósofo en el Teatro de la Cruz:

\section{DÍA ENTRADA}

$\begin{array}{ll}15 \text { de enero } & 6099 \\ 16 \text { de enero } & 6091 \\ 17 \text { de enero } & 4658 \\ 18 \text { de enero } & 4282 \\ 19 \text { de enero } & 7181 \\ 20 \text { de enero } & 4069 \\ 21 \text { de enero } & 2513\end{array}$

En total serían unos cinco mil reales diarios de recaudación. Lo que equivaldría a -según los cálculos anteriormente explicados- entre unos 9900 y 7700 euros actuales, según sea hecha la conversión. Un nuevo éxito claro para la producción de nuestro extremeño. La función que precedió a este texto, en su último día de permanencia en el mismo local, obtuvo 4030 reales. La pieza que la sucedió en escena, en su estreno, 6203 reales.

\subsection{Montajes en 1801}

Una vez más, el Diario de Madrid se hace eco de montajes de El Filósofo enamorado habidos en la Corte. En el año 1801 registra nada menos que tres escenificaciones de la pieza, que tienen lugar en los meses de agosto, septiembre y noviembre, todas llevadas a cabo en las tablas del Coliseo matritense de los Caños del Peral.

La primera de ellas tuvo lugar el jueves 13 de agosto de 1801: «Hoy á las 8 en punto de la noche, en el coliséo de los Caños del Peral, se executará por la compañía española, la comedia de figurón intitulada: La escuela de la amistad, ó el Filósofo enamorado, en tres actos seguidos, y por fin de fiesta la opereta en un acto intitulada: la Posaderita ${ }^{5}$. Se mantuvo sobre las tablas cuatro jornadas, los días 13, 14, 15 y 16 de agosto de ese año. La precedió en el mismo local «la pieza

5. Diario de Madrid, de esa fecha, p. 928. 
en dos actos intitulada: El Zeloso confundido, y la Prueba feliz” ${ }^{6}$. Fue sustituida, en el Coliseo de los Caños, por «el drama en tres actos intitulado: La Sophia, y la opereta titulada la casa de venta».

La función que incluía La escuela de la amistad como texto base estaba, como hemos podido comprobar, completada por "la opereta en un acto intitulada: la Posaderita», como fin de fiesta. Se iniciaba todos los días «á las 8 en punto de la noche». Los ejemplares del periódico correspondientes a las fechas de la representación no informan sobre los datos de recaudación obtenida en las sesiones. La "Compañía española» fue la que se encargó de la puesta en escena, sin que se incluyan datos del nombre de su director - de su «autor»- ni de los profesionales que formaban, entonces, parte de su plantilla.

La segunda escenificación fue estrenada el día 20 de septiembre, a las siete y media de la tarde (noche para los espectadores de 1801). Además de La escuela de la amistad la función ofrecía como complemento final La Guaracha: "En el de los Caños del Peral, á las 7 1/2 de la noche, se representa el drama en tres actos intitulado: La Escuela de la amistad, ó Filósofo enamorado, de figurón, dando fin con la Guaracha ${ }^{8}$. Se mantuvo una única jornada en cartel. Fue precedida, en el mismo local, por el espectáculo siguiente, montado el 19 de septiembre: "En el de los Caños del Peral, á las 7 1 1/2 de la noche, se representa los tres dramas cada uno en un acto intitulado: El Quadro, el Page, y la Corrección maternal ${ }^{9}$; y sustituida, el 21 de septiembre, por el siguiente: «En el de los Caños del Peral, á las 7 1⁄2 de la noche, se dará principio con la sinfonía de la Caza; seguirá la ópera de la casa de venta; se tocará la sinfonía oriental, y se concluirá con la pieza intitulada el Califa ${ }^{10}$. Como en la anterior representación, el Diario no proporciona datos de ingresos de taquilla ni sobre la compañía encargada de la función, que sería, con casi absoluta seguridad, la misma que se ocupó de la reposición del día 20 y la misma que se ocuparía de la escenificación del mes de noviembre del 1801, aunque la función, aquí, sí haya sufrido modificaciones, trocándose La Posaderita por La Guaracha.

El miércoles 11 de noviembre el periódico que manejamos se hace eco de otro montaje de El Filósofo enamorado: "En el de los Caños del Peral, á las 7 1/2 en punto, se executará la comedia en tres actos intitulada: La Escela de la amistad, ó Filósofo enamorado, concluyendose con la opera en un acto intitulada: La Posaderita ${ }^{11}$. Se trataba, claramente, de una reposición de la función exacta ofrecida el mes de agosto pasado. La hora de escenificación se había adelantado treinta minutos con respecto a esta. Este espectáculo también se mantuvo en cartel

6. Diario de Madrid, del miércoles 12 de agosto de 1801, p. 924.

7. Diario de Madrid, del lunes 17 de agosto de 1801, p. 944.

8. Diario de Madrid, del domingo 20 de septiembre de 1801, p. 1080.

9. Diario de Madrid, del sábado 19 de septiembre de 1801, p. 1076.

10. Diario de Madrid, del lunes 21 de septiembre de 1801, p. 1084.

11. Diario de Madrid, del miércoles 11 de noviembre de 1801, p. 1292. 
solo una jornada. Le precedió, en día 8 de noviembre ${ }^{12}$ : «En el de los Caños del Peral, á las 7 1 $1 / 2$ en punto, se executará el drama en tres actos, nuevo, intitulado: Las Sultanas ${ }^{13}$. Fue sucedido, el miércoles 11 de noviembre de 1801 con el siguiente programa: «En el de los Caños del Peral, á las 7 1⁄2 en punto, se executará la funcion siguiente: se dará principio con el drama en un acto intitulado: El Zeloso por fuerza; seguirá la opereta en un acto intitulada El crédulo desengañado, y se concluirá con la pieza tambien en un acto nominada La contradiccion, todo nuevo. // En celebridad del cumpleaños del Rey nuestro señor, que Dios guarde, se iluminarán los tres coliséos ${ }^{14}$. Carecemos, nuevamente, de datos de recaudación.

\subsection{Montajes en 1804}

En el mes de abril del año 1804 el Diario de Madrid anuncia una nueva puesta en escena de La escuela de la amistad. Su estreno se efectúa el jueves 19 de ese mes: «En el [Teatro] de la calle de la Cruz se representará la comedia titulada: $E l$ Filósofo Enamorado, de Figuron, con tonadilla y saynete por fin de fiesta: á las 5 . La entrada de ayer tarde fué de 3821 „15. Sustituía en escena a otra función descrita en el Diario de la siguiente forma: «En el de la calle de la Cruz se representará la comedia titulada: La Moza de Cántaro, con una tonadilla nueva, la que cantará la Sra. Isabel Gamborino, nueva en estos teatros, y saynete por fin de fiesta: á las 5. La entrada de ayer tarde fué de $4556^{16}$. La nueva reposición se mantuvo en cartel durante cinco jornadas, los días 19, 20, 21, 22 y $23^{17}$. El lunes 24 de abril fue sustituida por el siguiente espectáculo: «En el de la calle de la Cruz se representará la comedia titulada: El Viejo y la Niña, con tonadilla y saynete por fin de fiesta: á las 5. // Hace de primera Actriz la Sra. María García. // La entrada de ayer tarde fué de 3629" ${ }^{18}$.

Durante todos los días de representación la función dio comienzo a las cinco de la tarde, y su estructura no sufrió modificaciones, aunque desconocemos, por la fuente que utilizamos, el Diario de Madrid, los títulos de la tonadilla y en sainete que servían de fin de fiesta al espectáculo. Tampoco se ofrecen datos sobre la compañía encargada de este último. De lo que sí proporciona información el

12. El Diario del lunes 9 de noviembre de 1801 (p. 1284) explica: "La funcion del Coliseo de los Caños del Peral, se anunciará por carteles». En el ejemplar del martes 10 de noviembre de 1801 (p. 1288) solo se mencionan los Teatros de la Cruz y del Príncipe, no el Coliseo de los Caños del Peral.

13. Diario de Madrid, del domingo 8 de noviembre de 1801, p. 1280.

14. Diario de Madrid, del jueves 12 de noviembre de 1801, p. 1296.

15. Diario de Madrid, del jueves 19 de abril de 1804, p. 440.

16. Diario de Madrid, del miércoles 18 de abril de 1804, p. 436.

17. Diario de Madrid, del viernes 20 de abril de 1804, p. 444; del sábado 21 de abril de 1804, p. 448; del domingo 22 de abril de 1804, p. 454; del lunes 23 de abril de 1804, p. 459.

18. Diario de Madrid, del lunes 23 de abril de 1804, p. 459. 
periódico es de las recaudaciones de taquilla obtenidas durante los días del montaje. Fueron las siguientes:

$\begin{array}{cc}\text { Día } & \text { ENTRADA } \\ \text { 19 de abril } & 6285 \\ 20 \text { de abril } & 5661 \\ 21 \text { de abril } & 3620 \\ 22 \text { de abril } & 5355 \\ 23 \text { de abril } & 3629\end{array}$

De nuevo nos hallamos ante una muy aceptable media de unos cinco mil reales de ingresos diarios, entre unos 9900 y 7700 euros por jornada.

\subsection{Montajes en 1808}

Varios periódicos de 1808 insertan referencias a montajes de El Filósofo que tuvieron lugar en ese mismo año. Fueron, en concreto, el Diario de Madrid, el Memorial Literario y Minerva.

El Diario de Madrid es, de todos ellos, el que más información proporciona, como ha venido siendo habitual, según hemos podido venir comprobando en las páginas de nuestro artículo. Esta publicación recoge que, el sábado 30 de enero de $1808^{19}$, en Madrid, "En el coliseo de la Cruz, á las 5 de la tarde, se representará la comedia de figuron, titulada El Filósofo enamorado, con tonadilla y saynete». El estreno de esta reposición se efectúa pocos meses antes de estallar la guerra de la Independencia española contra Napoleón y sus ejércitos invasores. Se mantuvo la obra tres días en las tablas del mismo local: 30 y 31 de enero y 1 de febrero. Sustituyó en la escena a una "comedia nueva, en 5 actos, traducida del francés, titulada La Fortuna ciega á todos. ó el Titiritero filósofo, con una tonadilla general, intermediada del bolero á tres ${ }^{20}$. Fue sustituida, el día 2 de febrero de 1808, por "la comedia titulada Cecilia y Dorson, con tonadilla y saynete»" No se informa sobre la identidad y la composición de la compañía encargada del montaje. Sí, como hemos comprobado, sobre la estructura de la función, integrada, además de por El Filósofo, por una tonadilla y un sainete -tal vez como fin de fiesta- cuyos títulos no se explicitan. También, sobre el horario de las representaciones, que,

19. Ejemplar de esa fecha, p. 132.

20. Diario de Madrid, del viernes 29 de enero de 1808, p. 128.

21. Diario de Madrid, del martes 2 de febrero de 1808, p. 144. 
en los tres días que se mantuvieron en escena, tuvieron lugar, sistemáticamente, a las cinco de la tarde.

Los beneficios que en esta ocasión proporcionó el espectáculo a sus seguidores fueron inferiores a los registrados en representaciones anteriores -en el tiempo- de la obra de Forner. Según el Diario de Madrid ${ }^{22}$, fueron los siguientes:

\section{DÍA ENTRADA}

30 de enero 2479

31 de enero $\quad 4014$

1 de febrero 1656

En total, una media diaria de cerca de tres mil reales ${ }^{23}$. La recaudación en el último día en cartel de su obra predecesora fue de 2534 reales $^{24}$. La propia de su obra sustituta en el día de su estreno fue de $2616^{25}$.

La información proporcionada sobre espectáculos montados sobre La escuela de la amistad en Madrid, en el año 1808, es más escueta en el Memorial Literario y en la Minerva.

En el n. ${ }^{\circ} 9$ del Memorial Literario ó Biblioteca Periódica de Ciencias, Literatura y Artes, fechado el Dia 30 de Marzo de 1808. = Trimestre primero, en su sección destinada a "TEATROS", en el apartado "Noticia de las Representaciones executadas en el mes de Enero anterior en los tres Teatros de esta Corte» (pp. 228-229), explica que, en el Teatro de la Cruz madrileño, fue montada el «Dia 30. La Comedia titulada: El Filósofo enamorado, que duró tres dias» y produjo unos beneficios de 8204 reales $^{26}$. Las fechas de las representaciones coinciden con las proporcionadas por el Diario de Madrid y la Minerva. No así, la información de la recaudación obtenida, pues, según el Diario los ingresos totales de los tres días de funciones sumaron un total de 8140 reales, número algo inferior al que recoge el Memorial, pero coincidente con el que ofrece la Minerva ó El Revisor General (Obra periódica. Continua XL Trimestre noveno. Miscelánea.- Crítica. Tomo VIII. 1807. En la Imprenta de Vega y Compañía. Con Privilegio de S. M.), en cuya página 224 del número mencionado, en su sección de "TEATROS», en la parte dedicada al "Coliseo de la Cruz", indica que «el día 30 de enero se representó la comedia titulada: el Filósofo enamorado; ha durado tres dias, y producido 8204 reales».

22. Diario de Madrid, del domingo 31 de enero de 1808, p 136; del lunes 1 de febrero de 1808, p. 140; del martes 2 de febrero de 1808, p. 144.

23. Aproximadamente, entre unos 5940 y unos 4620 euros diarios actuales.

24. Diario de Madrid, del sábado 30 de enero de 1808, p. 132.

25. Diario de Madrid, del miércoles 3 de febrero de 1808, p. 148.

26. Según las conversiones que venimos efectuando, basándonos en expertos en la materia, entre unos 6304,32 y unos 4903,36 euros. 
Por su parte la Minerva recoge otro montaje de 1808 de La escuela de la amistad, de la que también se hace eco el Diario de Madrid. El volumen de la primera publicación, en cuya portada figuran los siguientes datos: Minerva, Obra periódica. El Misántropo y El Revisor ó Revista de las Costumbres, en que se forma un quadro verdadero de las de este siglo, y se comprehende la Revista Literaria ó idea del actual estado de las ciencias. Miscelánea.- Crítica. Tomo IX. 1808. (En la Imprenta de Vega y Compañía. Con Privilegio de S. M.) n. ${ }^{2}$ 27.-Abril 1 de 1808, en su página 48, da cobijo a una noticia que tuvo lugar en el mes de marzo de ese mismo año 1808. Indica que, en el Coliseo de la Cruz de la capital de las Españas, «El dia 26 [de marzo] se representó la comedia titulada: el Filosofo enamorado; ha durado dos dias y producido 3184 rs. ${ }^{27}{ }^{\text {». }}$

El Diario de Madrid proporciona mayores detalles, como es habitual en él. En la página 384 de su ejemplar correspondiente al sábado 26 de marzo de 1808, se encuentra la siguiente noticia: "En el coliseo de la Cruz, á las 5 de la tarde, se executará la comedia de figuron, titulada El Filósofo enamorado, se baylará el bolero, se cantará una tonadilla, y se concluirá con un saynete». Era el anuncio del estreno de una nueva reposición del texto compuesto por el emeritense. Probablemente se trata del mismo montaje que subió a las tablas del teatro de la Cruz de Madrid, el 30 de enero de este mismo año. Como en los diarios del mes de enero y de febrero, no se incluye el nombre de la compañía encargada de la función ni el de las personas que, entonces, formaban parte de ella y se repartieron los papeles de esa pieza. Sí, la hora de inicio de esta en el local: las cinco de la tarde, el 26 de marzo; y las cuatro y media, el 27 de marzo ${ }^{28}$. También las partes que la integraron: la creación de Forner, y -seguramente como fin de fiesta- un bolero -que no existía en el espectáculo de enero-febrero-, una tonadilla y un sainete, cuyos títulos no se especifican.

Las funciones se escenificaron en el escenario del Teatro de la Cruz, como hemos visto. El montaje de La escuela de la amistad, en esta ocasión, sustituyó al siguiente espectáculo: "En el coliseo de la Cruz, á las 5 de la tarde, se executará el oratorio sacro, antiguo, titulado Hacer su papel de veras, y mejor Representante, San Ginés». Y fue sustituido -tras breve paréntesis (los días 27 y 28 de marzo) debido a la acogida en ese local de la función ("El Divorcio por amor, con tonadilla,

27. Entre 6304,32 y 4903,36 euros.

28. Diario de Madrid, del domingo 27 de marzo de 1808 (p. 388), proporciona la clave para comprender el adelanto del horario con respecto a la función del día anterior. Se debió a que, a las ocho de la tarde de esa misma jornada, en el mismo Teatro de la Cruz, "se executará la comedia titulada El Divorcio por amor, con tonadilla, fandango, y saynete por fin de fiesta. // Nota. Esta función es la que se debia executar en el teatro de los Caños del Peral, que no su puede hacer por estarse componiendo, y de consiguiente los señores abonados acudirán al despacho de billetes por los que corresponden á las posesiones que ocupan en dicho teatro. Se advierte que los billetes de la función de la noche dirán Viérnes». 
fandango, y saynete por fin de fiesta» ${ }^{29}$ que estaba prevista para el Teatro de los Caños del Peral- por el siguiente: "A las 8 de la noche se executará en el de la Cruz la comedia titulada No puede ser guardar una muger, con tonadilla, bolero y saynete por fin de fiesta ${ }^{30}$.

De esta puesta en escena de marzo, conocemos, también, los datos de recaudación gracias al Diario $^{31}$ :

$\begin{array}{cc}\text { Día } & \text { ENTRADA } \\ 26 \text { de marzo } & 2378 \\ 27 \text { de marzo } & 806\end{array}$

Una cantidad total, entre las dos jornadas, de 3184 reales (entre unos 6304,32 y unos 4903,36 euros). La obra que la precedió en las tablas obtuvo 1023 reales de entrada ${ }^{32}$. La que la sustituyó, 2888 reales $^{33}$. Las cifras totales de recaudación de El Filófofo enamorado en esta reposición que figuran en el Diario de Madrid coinciden exactamente con las proporcionadas por Minerva, Obra periódica. El Misántropo y El Revisor ó Revista de las Costumbres: "El Filosofo enamorado; ha [...] producido $3184 \mathrm{rs}$.».

\subsection{Montajes en 1809}

En 1809 el Diario de Madrid se hace eco de una nueva reposición de El Filósofo enamorado. Tuvo lugar en el Teatro del Príncipe de la Corte, los días 17 y 18 de septiembre: «En el teatro del Principe, á las 7 de la noche, se representará la comedia titulada El Filósofo enamorado, ó la prueba de la amistad, con tonadilla y sainete ${ }^{34}$. La hora de inicio de las dos funciones fue siempre la misma. Las piezas breves que las completaron, seguramente como fin de fiesta (aunque no se informa de ello), tampoco fueron objeto de cambios, y en ambos anuncios del Diario no se especifican sus títulos.

29. Diario de Madrid, del domingo 27 de marzo de 1808, p. 388; y del lunes 28 de marzo, p. 392

30. Diario de Madrid, del martes 29 de marzo de 1808, p. 396.

31. Diario de Madrid, del domingo 27 de marzo de 1808, p. 388; y del lunes 28 de marzo, p. 392.

32. Diario de Madrid, del jueves 24 de marzo de 1808, p. 376.

33. Diario de Madrid, del jueves 31 de marzo de 1808, p. 404.

34. Diario de Madrid, del domingo 17 de septiembre de 1809, p. 316; y del lunes 18 de septiembre de 1809 , p. 320 
La representación del día 17 sustituyó a una función compuesta por la «COmedia, en 5 actos, titulada El Egoista ${ }^{35}$, y la opereta El Engañador engañado ${ }^{36}$, que había tenido lugar anterior día 15 de septiembre, en el mismo lugar y a la misma hora. La del día 18 fue sustituida, el día 20 de septiembre, por otra función formada por "la Comedia titulada Casa con dos puertas mala es de guardar ${ }^{37}$ con tonadilla y un divertido sainete ${ }^{38}$. En ningún caso, el Diario de Madrid, a diferencia de otras ocasiones, transmite cifras de recaudación.

\subsection{Montajes en 1811}

El Diario de Palma, en 1811, recoge en sus páginas noticias de un montaje de La prueba de la amistad que tuvo lugar en esa ciudad de la isla de Mallorca. Es -salvando los estrenos, en el siglo XVIII y en vida de Juan Pablo Forner, gaditanos y sevillanos de los que nos ocupamos con anterioridad- la primera representación del texto del emeritense localizada, en el siglo XIX, fuera de Madrid.

Se produjo este montaje en las Islas Baleares, en concreto en Palma de Mallorca. Los ejemplares del Diario de Palma que reflejaron tales funciones decimonónicas fueron los correspondientes a los días 21 y 22 de diciembre de 1811: "Teatro. Hoy se representa por la compañía cómica la comedia de figuron titulada: la escuela de la amistad y filósofo enamorado, con tonadilla, bayle y saynete» ${ }^{39}$. Como vemos no se especifica la hora a la que se inicia la función, ni la compañía concreta que se encargó del montaje. Tampoco sabemos si las piezas breves se incluyeron, como es probable, o no, al final de la comedia. Ni la recaudación obtenida. Sí sabemos los textos que precedieron y sustituyeron en las tablas a la creación de Forner: el primero fue "la comedia titulada: la Moza de Cántaro, con tonadilla, bayle y saynete ${ }^{40}$ (seguramente la compuesta por Lope de Vega) y el segundo, la "comedia nueva en este teatro titulada: el mayor Palmer, con tonadilla y saynete» ${ }^{41}$ (tal vez la escrita por Félix Enciso Castrillón).

35. Podría tratarse de la obra así titulada de M. ${ }^{a}$ Rosa Gálvez (cf. Gálvez, M. ${ }^{a}$ Rosa. El egoísta. Safo. en Luque, Aurora y Cabrera, José Luis. El valor de una ilustrada. María Rosa Gálvez. Málaga: Instituto Municipal del Libro, 2005, pp. 173-271) o de El Egoísta de José Mor de Fuentes (cf. Mor de Fuentes, José. Prólogo a la mujer varonil. Loa para el día de San Fernando. El Egoísta o el mal patriota. La fonda de París. Ed. Fernando Doménech Rico y Juan Antonio Hormigón. Madrid: Publicaciones de la Asociación de Directores de Escena de España, 1990. Serie Literatura Dramática, 13).

36. Diario de Madrid, del viernes 15 de septiembre de 1809, p. 308.

37. Comedia de Pedro Calderón de la Barca.

38. Diario de Madrid, del miércoles 20 de septiembre de 1809, p. 328.

39. Diario de Palma, del sábado 21 de diciembre de 1811, p. 460; y del domingo 22 de diciembre de 1811, p. 464.

40. Diario de Palma, del jueves 19 de diciembre de 1811, p. 452.

41. Diario de Palma, del lunes 23 de diciembre de 1811, p. 468. 


\subsection{Montajes en 1813}

El segundo montaje, fuera de Madrid, de El Filósofo enamorado que, en el siglo XIX, hemos podido documentar, lo registramos en Cádiz. Aparece recogido en esta ciudad, en el número 22 del periódico El Conciso, del lunes 22 de febrero de 1813, "Año $6^{\circ}$ de la gloriosa lucha del pueblo español contra la tiranía». Allí, en su página 7, podemos leer: «TEATRO. = Sinfonía á grande Orquesta. = El filosofo enamorado, comedia en tres actos. $=$ Un duo. $=$ Boleras. $=$ Saynete.$=$ Iluminacion. $=\mathrm{A}$ beneficio del exército. = A las siete y media». Se trató de un espectáculo múltiple, variado, en el que se incluyeron diversos ingredientes distintos, apto para atraer a un buen número de espectadores que pudieran proporcionar - "A beneficio del exército", como bien se indica- unos buenos ingresos a sus promotores, aunque, por esta fuente, no sabemos si de tal modo aconteció, pues el diario, en sus números de los siguientes días, no incluye datos sobre la recaudación obtenida. La función fue única, no fue repetida en ninguna otra jornada. El día 23 de febrero de 1813 fue estrenado otro espectáculo que es descrito de esta manera en el número 23 de El Conciso: "TEATRO. = El picarillo en España ${ }^{42}$, comedia en tres actos. $=$ Un duo. $=$ Bayle. $=$ Saynete. $=$ A las siete y media $"$ "

La función gaditana que nos ocupa fue precedida por otra anterior, del día 20 de febrero de 1813, que incluía un montaje de Raquel, seguramente la tragedia de Vicente García de la Huerta: "TEATRO. = Las esposas vengadas, pieza en 1 acto. = Tonadilla. = Bayle, máscaras \&c., como ayer. = Saynete. = A las 5. // La Raquel, tragedia en 3 actos. $=$ Tonadilla. $=$ Manchegas. $=$ Saynete.$=$ A las $8{ }^{44}$.

\subsection{Montajes en 1814}

En 1814 el Diario de Madrid proporciona información sobre otra reposición de La escuela de la amistad que tuvo lugar en la Villa y Corte. Se realizó en el Teatro de la Cruz, como había sido habitual en otras ocasiones. Fue anunciada en el ejemplar del periódico aparecido el 9 de octubre de ese año: «Mañana lunes, en el referido teatro [de la Cruz] se representará la comedia original del celebre español D. Pablo Forner, titulada el Filósofo enamorado, ó escuela de la amistad, en la que hará el principal papel el señor Mariano Querol» ${ }^{45}$. Es la primera mención que hemos encontrado en la prensa del nombre del autor que compuso la obra que nos ocupa.

42. Casi con seguridad se trate de la comedia El Picarillo en España, Señor de la Gran Canaria, de José de Cañizares.

43. El Conciso, n. ${ }^{\circ} 23$, del martes 23 de febrero de 1813, "Año $6^{\circ}$ de la gloriosa lucha del pueblo español contra la tiranía", p. 7. Cádiz: Imprenta de. D. Manuel Ximenez Carreño, calle Ancha.

44. El Conciso, n. ${ }^{\circ} 21$, del sábado 20 de febrero de 1813 , "Año $6^{\circ}$ de la gloriosa lucha del pueblo español contra la tiranía”, p. 7. Cádiz: Imprenta de. D. Manuel Ximenez Carreño, calle Ancha.

45. Diario de Madrid, del lunes 10 de octubre de 1814, p. 400. 
Efectivamente, este reestreno del Filósofo tuvo lugar, en el Teatro de la Cruz, el lunes 10 de octubre de 1814: "En el de la Cruz, á las 7 de la noche, se executará la comedia original del célebre español D. Pablo Forner, titulada el Filósofo enamorado, ó Escuela de la amistad, en la que hará el principal papel el señor Mariano Querol, con tonadilla y sainete» ${ }^{46}$. La obra permaneció en cartel los días 11 y 12 de octubre. Fueron en total tres jornadas de representaciones.

Desconocemos, por el Diario, quién era el autor de la compañía que se encargó de este montaje. Sí figuran en él, como luego comprobaremos, los nombres de algunos de los cómicos que formaban entonces parte de ella. Así, además de Mariano Querol, mencionan en el periódico a "Loreto García», "la señora Molino y el señor Sandalio", "las señoras Valdes y Carreras, y los señores González y Gamborino».

La estructura de las funciones, al igual que el comienzo de las mismas («á las 7 de la noche»), fue siempre idéntica en todos los días de representaciones. Constaban de la comedia de Forner, acompañada -tal vez como fin de fiesta, aunque no se especifica- "con tonadilla y sainete», como vimos.

El éxito de los montajes fue notable. Según los datos de recaudación proporcionados por el Diario $^{47}$, el público volvió a tributar una buena acogida a la creación del emeritense:

$\begin{array}{cc}\text { Día } & \text { ENTRADA } \\ 10 \text { de octubre } & 7900 \text { rs. } \\ 11 \text { de octubre } & 6010 \text { rs. } \\ 12 \text { de octubre } & 3660 \text { rs. }\end{array}$

Los ingresos totales de taquilla fueron 17570 reales, aproximadamente entre unos 34788,60 y 27057,80 euros.

La composición de Forner sustituyó en escena al siguiente espectáculo: «En el de la Cruz, á las 7 de la noche, se executará la comedia en 3 actos titulada el Perro del hortelano, en la que harán sus principales papeles la señora Agustina y el señor Carretero; boleras por la señora Carreras y Gamborino, y un buen sainete ${ }^{48}$. A su vez, fue sustituida por una función especial múltiple montada con motivo del cumpleaños del rey Fernando VII, que había comprometido su asistencia la noche del estreno, y que tuvo lugar el viernes 14 de octubre de 1814:

46. Diario de Madrid, del lunes 10 de octubre de 1814, p. 400.

47. Diario de Madrid, del martes 11 de octubre de 1814, p. 404; del miércoles 12 de octubre de 1814, p. 408; y del jueves 13 de octubre de 1814, p. 412.

48. Diario de Madrid, del domingo 9 de octubre de 1814, p. 396. 
En el de la Cruz, á las 6 1⁄2 de la noche, se representará la funcion siguiente: se dará principio con una armoniosa obertura; seguirá una loa alegórica al plausible dia del cumpleaños de nuestro amado Soberano; cantará una aria la señora Loreto García; seguirá la comedia titulada D. Gil de las calzas verdes; á la conclusión del primer acto bailarán boleras la señora Molino y el señor Sandalio; después del $2^{\circ}$ acto se bailarán manchegas por las señoras Valdes y Carreras, y los señores González y Gamborino; concluido el tercer acto se tocará la sinfonía de la Caza, y se dará fin con el baile titulado el Sultan generoso: y en celebridad de tan feliz objeto, y la grata asistencia de su augusta y Real Persona, estará decorado é iluminado el teatro, y se estrenará un nuevo telón de embocadura, pintado por el célebre profesor D. Zacarías Velazquez ${ }^{49}$.

Esta función fue posteriormente representada, con buena aceptación, durante dos días más, los días 15 y 16 del mismo mes. El día 17 volvió a aparecer en el Teatro de la Cruz, pero ya reducida: «á las 7 de la noche, se executará la comedia en 3 actos titulada D. Gil de las calzas verdes, se tocará la sinfonía de la Caza, y se concluirá con el baile titulado el Sultan generoso" ${ }^{50}$.

\subsection{Montajes en 1816}

En 1816, el Diario de Madrid recoge nada menos que dos montajes de La escuela de la amistad. Tuvieron lugar en el Teatro de la Cruz matritense, en los meses de junio y agosto.

En junio el Diario de Madrid del día 16, domingo, en su página 748, adelanta la siguiente función: «Mañana en este teatro [de la Cruz] se executará la comedia de figuron en 3 actos titulada el Filósofo enamorado, su autor D. Juan Pablo Forner». Efectivamente, el ejemplar del lunes 17 de junio de 1816, en su página 752, incluye la siguiente información: «TEATROS. En el de la Cruz, á las 8 de la noche, se executará la comedia de figuron en 3 actos titulada el Filósofo enamorado, ó la Escuela de la amistad, su autor D. Juan Pablo Forner; la señora Raimunda Bueno y el señor Francisco Bueno bailarán el bolero, y se dará fin con el sainete el Tio Bigornia. Actores en la comedia; señoras Ramos y Rafaela Gonzalez; señores Carretero, Querol, Perez, Gonzalez menor, Campos, Paz, Juan Perez y Andres Lopez. Entrada de anoche 4464 rs.». El estreno de la primera reposición, de 1816, del texto del emeritense se había en esa fecha producido.

La función de junio de 1816 se mantuvo en cartel tres días, el 17, el 18 y el 19. Comenzó, sistemáticamente, "á las 8 de la noche», y tuvo siempre la misma estructura: la comedia de Forner, un bolero bailado por "la señora Raimunda Bueno y el señor Francisco Bueno» y un sainete, estos dos últimos quizá como fin de fiesta. Lo que sí se modificó fue el sainete concreto que se presentó ante el espectador.

49. Diario de Madrid, del viernes 14 de octubre de 1814, p. 416

50. Diario de Madrid, del lunes 17 de octubre de 1814, p. 428. 
Los días 17 y 18 se montó «el Tio Bigornia»; el 19, "el Chupeno». La compañía, según refleja la prensa que manejamos, no sufrió en estos tres días ningún tipo de cambio en su composición. Todas las jornadas se citan los mismos nombres que hemos visto enumerados en el Diario del día del estreno de la reposición.

El Montaje de El Filósofo que nos ocupa fue precedido por uno anterior que es descrito por el Diario de Madrid, del domingo 16 de junio de 1816, en su página 748 , de la siguiente forma:

En el de la Cruz, á las 8. de la noche, se executará la función siguiente: principiará con la comedia antigua, refundida en 3 actos, titulada Encontrar un imposible, Muger fiel, y Amigo firme ${ }^{51}$; la señora Saldoni y el señor Mariano García bailarán el bolero, y se dará fin con el sainete el invisible apaleado. Actores en la comedia: señoras Carmona, Ramos y Rafaela Gonzalez: señores Carretero, Lopez, Diez, Ronda, Alverá, Campos, Juan Perez, Fernandez y Pacheco. Entrada de anoche 4248 rs.

Le sucedió el siguiente espectáculo:

En el de la Cruz, á las 8 de la noche, se executará el drama en 5 actos titulado $\mathrm{Al}$ amor de madre no hai afecto que le iguale, ó la Andrómaca ${ }^{52}$; y el baile nuevo heroico pantomimo, titulado Hércules en el jardin de Espero, puesto en escena por el señor José Barbieri. Actores en el drama: señoras Carmona, Ramos y Leon: señores Carretero, Lopez y Ronda. Id. en el baile: señoras Mexía, Saldoni, Buento, Justa Gonzalez \&c.: señores Gonzalez, Bueno, García, Cipres, Barba \&c. Entrada de anoche 3134 rs. [...] (Diario de Madrid, del jueves 20 de junio de 1816, p. 760).

El éxito obtenido, en este mes, por la pieza de Forner, fue similar al que obtuvo en otras reposiciones suyas anteriores. Los ingresos de taquilla que recaudaron las funciones, según el mismo Diario de Madrid que usamos como fuente, fueron los siguientes:

$\begin{array}{cc}\text { Día } & \text { ENTRADA } \\ 17 \text { de junio } & 5560 \mathrm{rs} . \\ 18 \text { de junio } & 4012 \mathrm{rs} . \\ 19 \text { de junio } & 3134 \mathrm{rs} .\end{array}$

La cantidad total fue 12706 reales, entre 25157,88 y 19567,24 euros actuales ${ }^{53}$. El ejemplar del Diario de Madrid del domingo 10 de noviembre de 1816, en sus páginas 595, 596 y 597, publica un «Articulo comunicado», dirigido al «Señor

51. Tal vez se trate de la refundición de una obra de Tirso de Molina, realizada por Dionisio Solís, también conocida como Pruebas de amor y amistad.

52. Obra popular de José Cumplido.

53. Véanse las cifras en Diario de Madrid, del martes 18 de junio de 1816, p. 756; del miércoles 19 de junio de 1816, p. 760; y del jueves 20 de junio de 1816, p. 764. 
diarista», que incluye una "nota del producto de las entradas de los teatros de esta corte, correspondiente al mes pasado de agosto, en los días de representacion, para que se sirva insertarla en su periódico como las anteriores». Allí se encuentran las cantidades totales recaudadas por cada comedia escenificada, en ese mes, en los Teatros de la Cruz y del Príncipe, así como los días que cada obra se mantuvo en cartel. Entre los datos que atañen al Teatro de la Cruz nos encontramos con la mención de un montaje, en él, de El Filósofo enamorado, que obtuvo unos ingresos de 3030 reales (entre 5999,4 y 4666,2 euros) en el único día en el que se ofreció a los espectadores (página 596). No se especifica cuál fue la fecha concreta en la que la obra de Forner fue puesta en escena. Revisados todos los ejemplares del mencionado Diario de Madrid impresos en agosto de 1816, no hemos hallado referencia específica a tal función en la que se incluía El Filósofo. No obstante, hay un día, el 22 de agosto de 1816, en el que el ejemplar correspondiente de ese periódico, en su sección de "Teatros», inserta en la página 224, se afirma: "La función que se ha de executar hoi en el de la Cruz se anunciará por carteles. Entrada de anoche 2550 rs.». Esta puede ser la ocasión en la que la creación de Juan Pablo Forner volvió a comparecer, de nuevo, y por segunda vez en 1816, ante su auditorio.

De esta representación no conservamos más datos. Pese a ello, podemos conjeturar que de su puesta en escena se encargó la misma compañía que ocupaba el Teatro de la Cruz en el mes de agosto de 1816, y cuya composición es detallada, al menos parcialmente, en el Diario de Madrid del viernes 16 de agosto de 1816, en cuya página 200 podemos leer:

En el de la Cruz, á las 8 de la noche, se executará la comedia en 3 actos titulada el Vergonzoso en palacio ${ }^{54}$; concluida, bailará un solo el señor Barba, intermediado por los señores Bueno, García, Cipres y figurantes, y se dará fin con el sainete la Estatua fingida. Actores en la comedia: señoras Baus, Ramos y Ramona Leon: señores Carretero, Perez, Lopez, Diez, Campos, Alverá, Juan Perez, Andres Lopez, Ribera, Pacheco \&c. Entrada de anoche 4690 rs.

Sabemos que el día siguiente de la posible, y probable, representación de $E l$ Filósofo, "En el de la Cruz no hai funcion" 55 .

La obra que precedió en las tablas a la escenificada el 22 de agosto de 1816 fue, según el Diario de ese día, la siguiente:

En el de la Cruz, á las 8 de la noche, se executará la comedia de figuron en 3 actos titulada el Lindo D. Diego ${ }^{56}$, concluida bailará el baile inglés el señor José Gonzalez, y se dará fin con el sainete Herir por los mismos filos. Actores en la comedia: señoras

54. Seguramente se trata de la comedia de Tirso de Molina.

55. Diario de Madrid, del viernes 23 de agosto de 1816, p. 228.

56. Probablemente, la pieza de Agustín Moreto. 
Ramos, Rafaela Gonzalez, Virg y Ramona Leon: señores Carretero, Querol, Lopez, Diez, Morales y Pacheco. Entrada de anoche 3516 rs. ${ }^{57}$.

La representación que la sucedió, según el Diario del sábado 24 de agosto de 2016, fue: "En el de la Cruz, á las 8 de la noche, se executará la comedia en 3 actos titulada la Viuda generosa ${ }^{58}$; la señora Molino y el señor Barba bailarán un padedú, y se dará fin con el sainete el Page en la obligacion. Actores en la comedia: señoras Ramos, Rafaela Gonzalez, Virg y Ramona Leon: señores Carretero, Perez, Campos, Juan Perez, Paz y Morales ${ }^{59}$.

\subsection{Montajes en 1824}

Queda registrada otra nueva reposición de El Filósofo enamorado en el Diario de Madrid. Tuvo lugar en el año 1824, en su, ya tradicional, Teatro de la Cruz madrileño, en el mes de mayo. Fue anunciada en el Diario del jueves día 6 de ese mes: «Nota. Mañana viernes siete se egecutará la célebre comedia de figuron de D. Pablo Forner en 3 actos titulada la Escuela de la Amistad ó el Filósofo Enamorado» (p. 4). El texto debía de gozar de fama y predicamento entre el público del momento, dado que en tal anuncio se refieren a él como "la célebre comedia de figuron de D. Pablo Forner».

El estreno de la nueva función tuvo lugar, en el local previamente indicado, el día 7 de mayo de 1925, a las ocho horas. Ya había sido anunciada en el Diario de Madrid, en los números de los dos días anteriores: el publicado el 5 de mayo (p. 4): «Nota. En seguida de esta funcion se egecutará la célebre comedia de figuron de D. Pablo Forner en 3 actos titulada la Escuela de la Amistad ó el Filósofo Enamorado»; y el correspondiente al 6 de mayo (p. 4): "Nota. Mañana viernes siete se egecutará la célebre comedia de figuron de D. Pablo Forner en 3 actos titulada la Escuela de la Amistad ó el Filósofo Enamorado». La obra permaneció en cartel los días siete y ocho de mayo, y el espectáculo se inició, en ambas jornadas, "á las 8 de la noche».

La estructura de la función fue idéntica en todos los días de su aparición ante los espectadores, como confirman los ejemplares del Diario editados el 7 y el 8 de mayo (pp. 4 y 8, respectivamente), así como la identidad de los cómicos que se encargaron del montaje:

En el de la Cruz, á las 8 de la noche, se ejecutará la célebre comedia de figuron de D. Pablo Forner, en 3 actos titulada la Escuela de la Amistad ó el Filósofo enamorado: á continuacion se bailarán bolera á cuatro por María Fabiani, Mariana Castillo,

57. Diario de Madrid, del miércoles 21 de agosto de 1816, p. 220.

58. Fermín del Rey tiene una comedia así titulada.

59. Diario de Madrid, del sábado 24 de agosto de 1816, p. 232. 
Antonio Fabiani y Francisco Bueno; y se terminará el espectáculo con el gracioso sainete titulado la Fantasma.

Actrices en la comedia. Sanchez, Paz y Virg. Actores. Carretero, Campos, Cubas, Prats, Perez, Fernandez, Perez y Gutierrez. Id. en el sainete. Virg, Sanchez, Paz, Leon, Pinto, Cubas y Alonso. P. Cubas, Lopez, Prata, Fernandez, Diez, Perez, Fernandez, G. Perez y Bailés.

Nota. Se está ensayando para egecutarse á la mayor brevedad el drama nuevo en 3 actos, traducido del frances titulado el Mendigo tocador de órgano.

En las páginas del Diario no se incluyen, en esta ocasión, datos de la recaudación obtenida de la venta de entradas en cada una de las representaciones.

El espectáculo al que sustituyó El Filósofo enamorado en el Teatro de la Cruz fue el siguiente:

En el de la Cruz, á las 8 de la noche, se egecutará la comedia en 3 actos titulada Ser fiel á su Soberano ó los Monteros de Espinosa ${ }^{60}$ : en seguida se bailara el boleto por Tomasa Cubas y Vicente Perales, y se finalizará el espectaculo con el divertido sainete titulado el Casado por fuerza. Actrices en la comedia. Baus, Sanchez, Virg, y Leon. Actores. Carretero, Martinez, Lopez, Prats, Cubas, Fernandez, Bailés y Gutiérrez. Id. en el sainete. Virg, Paz, Leon, y Pinto. Cubas, Fernandez, Prats, Diez y Ortigas ${ }^{61}$.

El que sustituyó a la comedia de Forner fue así anunciado: «En el de la Cruz, á las 8 de la noche, se egecutará la famosa comedia en 5 actos titulada el Duque de Pentiebre $^{62}$ : á continuacion se bailará el bolero á seis por María Fabiani, Mariana Castillo y Tomasa Cubas; Antonio Fabiani, Francisco Bueno y Vicente Perales, y se finalizará el espectáculo con el divertido sainete titulado el Tordo» ${ }^{63}$.

\subsection{Montajes en 1828}

En 1828 un nuevo montaje de La escuela de la amistad queda registrado en las páginas del Diario de Avisos de Madrid. En los números correspondientes a los días 14, 15 y 16 de junio (pp. 664, 668 y 672) figura debidamente anunciado su próximo estreno: "Se está ensayando para poner en escena muy en breve la comedia de carácter en tres actos titulado El Filósofo enamorado, ó la Escuela de la amistad, compuesta por D. Juan Pablo Forner, magistrado español, bien conocido entre los amantes de las buenas letras por el mérito de sus obras». En este anuncio se demuestra la aceptación, y reconocimiento por parte del auditorio, de

60. Tal vez se trate de una comedia de Lope refundida en el siglo XVIII por Antonio Valladares de Sotomayor.

61. Diario de Madrid, del jueves 6 de mayo de 1824, p. 4.

62. Quizá la traducción de Fenelon, ou les religieuses de Cambrai, de Chenier, debida a Vicente Rodríguez de Arellano.

63. Diario de Madrid, del domingo 9 de mayo de 1824, p. 4. 
la que goza habitualmente la comedia repuesta y la figura de su autor: «El Filósofo enamorado, ó la Escuela de la amistad, compuesta por D. Juan Pablo Forner, magistrado español, bien conocido entre los amantes de las buenas letras por el mérito de sus obras». El texto ya no es identificado como comedia de figurón, sino «de carácter».

El espectáculo que contiene El Filósofo es estrenado el día 18. Permaneció dos días sobre las tablas, el 18 y el 19. Constaba, como era habitual, de diferentes partes: "En el de la Cruz, á las ocho de la noche: El Filósofo enamorado, ó la Escuela de la amistad, comedia de caracter en tres actos, compuesta por D. Juan Pablo Forner, magistrado español, bien conocido entre los amantes de las buenas letras por el mérito de sus obras: en seguida se bailarán manchegas por la Sra. Diez y el Sr. Luengo, dando fin á la funcion con el sainete titulado Los maridos engañados y desengañados ${ }^{64}$.

La función se inició sistemáticamente a las ocho de la tarde, y sufrió, el día posterior a su primera presentación ante el público, un breve cambio interno, pues las manchegas que se bailaron "la Sra. Diez y el Sr. Luengo» el día 18, según hemos leído, fueron trocadas, el día 19, por un bolero, bailado por «la Sra. Requejo y el Sr. Martinez" ${ }^{65}$.

El Diario de Avisos, en su publicación de los días 18 y 19 de junio (pp. 680 y 684), especifica, también, los nombres de los cómicos que formaban parte de la compañía encargada del montaje que estudiamos en este apartado: "Actores en la comedia: Sras. A. Baus, Samaniego y Virg. Sres. Lopez, Alcazar, R. Perez; P. Cubas, Campos \&c. Id. en el sainete: Sras. Virg, Leon y Luisa Cubas. Sres. P. Cubas, Alcazar, Tamayo, Campos, Inza y G. Fernandez».

La función, a diferencia de otras reposiciones, solo fue ofrecida a sus espectadores durante dos jornadas. Ello obedeció a un cambio, en esa temporada, de la estrategia comercial diseñada por el empresario, según se especifica, igualmente, en las páginas del Diario de Avisos de Madrid:

Nota. Persuadida la empresa a que de la variedad en el género de espectáculos que le ofrece á este ilustrado público puede resultar su placer, esta disponiendo para poner inmediatamente en escena la comedia en tres actos titulada el Buen hijo ó María Teresa de Austria, en la cual se ejecutarán con toda la posible propiedad muchas y diferentes evoluciones militares, que dando mas realce al interes del drama, concurran al fin á que la empresa aspira, que es el de merecer la aprobacion de los que asisten á uno y otro teatro ${ }^{66}$.

64. Diario de Avisos de Madrid, del miércoles 18 de junio de 1828, p. 680.

65. Diario de Avisos de Madrid, del jueves 19 de junio de 1828, p. 684.

66. Diario de Avisos de Madrid, del jueves 19 de junio de 1828, p. 684. 
En esta ocasión, los periódicos manejados no ofrecen, a sus lectores interesados, datos sobre las recaudaciones obtenidas en taquilla durante las fechas de escenificación, en 1828, de la obra de Forner.

La función La escuela de la amistad sustituyó en la escena del Teatro de la Cruz al siguiente espectáculo del día 17 de junio: «En el de la Cruz, á las ocho de la noche: El Barón de Fechein ${ }^{67}$, ópera semiseria en dos actos, musica del célebre maestro Pacini. Actores: Sras. Albini y Mascias. Sres. Valencia, Benetti, Rossi, Llord, Rodriguez, Mata y coristas " ${ }^{68}$. A su vez, fue sustituida, el día 20 de junio, por el siguiente montaje:

En el de la Cruz, á las ocho de la noche: ¡Si no vieran las mugeres! comedia nueva en cinco actos del célebre Lope de Vega Carpio, refundida últimamente por D. Manuel Breton de los Herreros: á continuación se bailará el boleto por la Sra. Requejo y el Sr. Martínez; dando fin á la funcion con el sainete titulado El Sueño. Actores en la comedia: Sras. A. Baus, y Virg. Sres. García Luna, Tamayo, Alcázar, R. Perez, P. Cubas \&c. Id. en el sainete: Sras. Virg, Leon, Bravo y Caset. Sres. P. Cubas, Alcazar, Campos, Inza, G. Fernandez y Aguado ${ }^{69}$.

\subsection{El no montaje de 1829}

La Gazeta de Bayona, en su número 52, del lunes 30 de marzo de 1829, en su página 3, informa sobre un juicio negativo, ante la posibilidad de una lectura o de un montaje de El Filósofo enamorado en la diócesis de Valencia, por parte de la autoridad eclesiástica entonces competente, lanzando el obispo de la ciudad, sobre la pieza de nuestro extremeño, un anatema por motivos de censura moral, ya que la juzga texto muy inconveniente para los lectores o espectadores de su tiempo:

VALENCIA, 18 de marzo. - Nuestro Exmo. Sr. arzobispo ha publicado una pastoral propia de su zelo é ilustración, recomendando á sus diocesanos la necesidad de reformar sus costumbres y aprovecharse del santo tiempo de cuaresma, para desechar los vicios mas comunes en este arzobispado. Y como uno de los manantiales mas funestos de ellos sea la perniciosa lectura de libros impíos, heréticos, escandalosos y subversivos, ha publicado un edicto bastante estenso, en que se prohiben diferentes obras en francés, en latín, en italiano y en español; y particularmente un gran número de tragedias y comedias, muchas de las cuales se representan con frecuencia en los teatros de la corte y de las provincias. Hay en efecto algunas que cuando ménos necesitarian un severo espurgo para no ser nocivas a las costumbres y al buen gusto; pero convendría sobre todo que hubiese uniformidad en las reglas que

67. Se trata del melodrama Il Barone di Dolsheim, cuyo libreto fue obra de Felice Romani, y que fue estrenado en el Teatro de la Scala de Milán, el 23 de septiembre de 1818.

68. Diario de Avisos de Madrid, del martes 17 de junio de 1828, p. 676.

69. Diario de Avisos de Madrid, del viernes 20 de junio de 1828, p. 688. 
se diesen de licitud ó ilicitud de las piezas dramáticos que se presentan al público; porque no puede menos da inquietar la conciencia de las almas piadosas el ver que las comedias "Si no vieran las mugeres, Cuantas veo tantas quiero, el Mayor monstruo los celos y Tetrarca de Jerusalen, No hay contra un padre razón, la Escuela de la amistad ó Filósofo enamorado, el Filósofo casado o Marido avergonzado de serlo, el Sabio en su retiro y Villano en su rincon, el Viejo y la Niña, las Cárceles de Lemberg, Caprichos de amor y celos, D. Gil de las calzas verdes, el Poder de la Inocencia, los Amantes generosos, Indulgencia para todos, el Convidado de Piedra, Juana la Rabicortona, los Viages de Pedro el grande, el Hechizado por fuerza", y otras muchas de las 189 piezas que se prohiben en el edicto de nuestro respetable prelado, sean licitas y corrientes en otras provincias de la monarquia, representándose con permiso de la autoridad eclesiástica y civil, y no puedan representarse ni leerse en Valencia, bajo la pena de escomunion latae sententiae ipso facto incurrenda.

Se trata de una clara prueba de la notoriedad y aceptación de la que gozaba la comedia de Juan Pablo Forner entre los receptores de las postrimerías de la Ilustración, al ser explícitamente enumerada junto a otros textos muy famosos en la época, de grandes y admirados autores como Lope de Vega, Calderón de la Barca, José de Cañizares, Leandro Fernández de Moratín...

\subsection{Montajes en 1830}

En la Corte matritense se producen nuevas reposiciones de La escuela de la amistad en el año 1830. En concreto, El Diario de Avisos de Madrid se hace eco de dos de ellas que tuvieron lugar en los meses de septiembre y octubre. En los ejemplares correspondientes del periódico, como viene siendo habitual desde el año 1824, no se insertan datos sobre los ingresos de taquilla proporcionados por los montajes.

El primer montaje de la pieza tiene lugar en el Teatro madrileño de la Cruz, como viene siendo habitual en los últimos años que hemos estudiado. Es anunciado, antes de su primera puesta en escena, en los ejemplares del Diario de Avisos correspondientes a los días 5 y 6 de septiembre de 1830 (pp. 1000 y 1004), respectivamente: «En seguida de esta funcion se ejecutará la comedia de caracter en tres actos titulada El Filósofo enamorado ó la escuela de la amistad, compuesta por D. Juan Pablo Forner, magistrado español, bien conocido entre los amantes de las buenas letras por el mérito de sus obras», y «Mañana se ejecutará la comedia antigua de caracter en tres actos titulada El Filósofo enamorado ó la escuela de la amistad, compuesta por D. Juan Pablo Forner, magistrado español, bien conocido entre los amantes de las buenas letras por el mérito de sus obras». El Filósofo enamorado es mencionado, como aquí comprobamos, con gran respeto y reconocimiento para él y para su creador, que es citado, por vez primera en los periódicos que hemos manejado, con su nombre, Juan Pablo, completo.

El estreno de la función se produjo el día 7 de septiembre de 1830: 
En el de la Cruz, á las siete y media de la noche: El Filósofo enamorado ó la Escuela de la amistad, comedia antigua de carácter en tres actos compuesta por D. Juan Pablo Forner, magistrado español, bien conocido entre los amantes de las buenas letras por el mérito de sus obras. A continuacion se bailarán las boleras nuevas del Serení por la Sra. Dubiñon y el Sr. Camprubi; terminándose la funcion con el sainete titulado La estatua fingida. Actores en la comedia: Sras. A. Baus, T. Baus y F. Rodríguez. Sres. R. Lopez, Tamayo, P. Cubas, Campos, P. Lopez, Orgaz \&c. Id. en el sainete: Sras. F. Rodriguez y Delgado: Sres. Orgaz, Campos, P. Lopez \&c. ${ }^{70}$.

Se mantuvo un día más, el 8, en cartel, hasta el 9 de septiembre de 1830, en el que el Diario de Avisos de Madrid de esa fecha (p. 1016) anuncia:

En el de la Cruz, á las siete y media de la noche: Para servirte me caso, ó La novia tapada, comedia en tres actos. A continuacion se bailará el bolero por la señora Diez y Font; terminándose la funcion con el sainete titulado Los Payos. Actores en la comedia: Sras. T. Baus, Ridaura y F. Rodriguez: Sres. Tamayo, Valero, José Cubas. Campos, P. Lopez y Robreño. Id. en el sainete: Sras. F. Rodriguez y Delgado. Sres. José Cubas y Campos.

Había sustituido a otra previa que, en el mismo periódico, es descrita del siguiente modo:

En el de la Cruz, á las siete y media de la noche: Un Bobo hace ciento, comedia antigua en tres actos de D. Antonio Solís, una de las mas ingeniosas de este autor. A continuación se bailará el bolero por la Sra. Castillo y el Sr. Ibañez; terminándose la función con el sainete titulado las Cuatro bodas. Actores en la comedia: Sras. A. Baus, Bravo, F. Rodríguez y R. Pinto: Sres Montano, Tamayo, P. Cubes \&c. Id. en el sainete: Sras. F. Rodriguez, Delgado, Leon y R. Pinto: Sres. José Cubas, Camino, Robleño y Juan Cubas ${ }^{71}$.

En los dos días de su presencia en escena la función fue invariablemente iniciada a las siete y media de la tarde (noche para la época). Su composición tuvo variaciones en esas jornadas. El sainete del día 7 que sirvió como fin de fiesta, como hemos visto, fue La estatua fingida. En el día 8, en el anuncio del Diario, se indica que el título del sainete de cierre de espectáculo era El Remendón y la Prendera:

En el de la Cruz, á las siete y media de la noche: El Filósofo enamorado ó la Escuela de la amistad, comedia antigua de caracter en tres actos compuesta por D. Juan Pablo Forner, magistrado español, bien conocido entre los amantes de las buenas letras por el mérito de sus obras. A continuacion se bailarán las boleras nuevas del Serení por la Sra. Dubiñon y el Sr. Camprubi; terminándose la funcion con el sainete titulado El Remendón y la Prendera. Actores en la comedia: Sras. A. Baus, T. Baus

70. Diario de Avisos de Madrid, del martes 7 de septiembre de 1830, p. 1008.

71. Diario de Avisos de Madrid, del lunes 6 de septiembre de 1830, p. 1004. 
y F. Rodríguez. Sres. R. Lopez, Tamayo, P. Cubas, Campos, P. Lopez, \&c. Id. en el sainete: Sras. P. Rodriguez y R. Pinto: Sres. Juan Cubas, P. Lopez, Campos \&c. ${ }^{72}$.

La compañía mantuvo en estos dos días de espectáculo la misma composición, sin cambios en los repartos, salvo en la parte destinada a los sainetes, que, al ser dos diferentes, en cada uno de ellos se habían asignado los papeles a cómicos distintos, como reflejan los anuncios insertos los dos periódicos, el correspondiente al día 7 y el correspondiente al día 8, que hemos consultado, y antes reproducido.

El espectáculo de octubre de 1830 no fue sino una reposición del mismo montaje ya ofrecido a los espectadores en septiembre de ese año. Fue estrenado el día 2 de ese mes, en el que el Diario explica, en su sección de teatro:

En el de la Cruz á las siete de la noche: El Filósofo enamorado ó La Escuela de la amistad, comedia antigua de carácter en tres actos, su autor D. Juan Pablo Forner, magistrado español. A continuacion se bailará el bolero por la Sra. Castillo y el Sr. Ibañez; terminándose la funcion con el sainete titulado El Remendon y la Prendera. Actores en la comedia: Sras. A. Baus, T. Baus y F. Rodriguez. Sres. R. Lopez, Tamayo, P. Cubas \&c. Id. en el sainete: Sras. F. Rodriguez y R. Pinto. Sres. Juan Cubas, R. Lopez, Campos \&c. ${ }^{73}$.

Solo permaneció en escena en esa jornada. En la siguiente fue sustituido por otro así descrito por el mismo periódico: «En el de la Cruz á las siete de la noche: Gli Arabi nelle Gallie, ópera seria en dos actos, música del célebre maestro Pacini. Actores: Sras. Tossi, Lorenzani y Luisa de Antonio. Sres. Trezzini, Vaccani, Llord, Rodriguez y coristas ${ }^{74}$. Le había precedido otro ofrecido a su auditorio el día 1 de octubre: «En el de la Cruz á las siete de la noche: La Esclava en Bagdad, ópera bufa en dos actos, música del célebre maestro Pacini. Actores: Sras. Corri Paltoni y Antonia Campos. Sres. Pasini, Inchindi, Vacani, Llord, Rodriguez y coristas ${ }^{75}$. Su escasa permanencia en las tablas sería seguramente debida a la política empresarial de introducir constantes mutaciones en las funciones ofrecidas a los espectadores para atraer mayor número de ellos a los locales madrileños, como explicaba el Diario de Avisos en ejemplares suyos de años anteriores, que hemos comentado, y reproducido la explicación impresa allí, en otro lugar.

\subsection{Montajes en 1834}

En agosto de 1834 el Diario de Avisos de Madrid anuncia una nueva reposición en la capital de España de la "comedia de carácter en tres actos» El Filósofo

72. Diario de Avisos de Madrid, del miércoles 8 de septiembre de 1830, p. 1012.

73. Diario de Avisos de Madrid, del martes 7 de septiembre de 1830, p. 1008.

74. Diario de Avisos de Madrid, del domingo 3 de octubre de 1830, p. 1112.

75. Diario de Avisos de Madrid, del viernes 1 de octubre de 1830, p. 1104. 
enamorado de Juan Pablo Forner, una vez más presentado, con reconocimiento y respeto, como "magistrado español, bien conocido entre los amantes de las buenas letras por el mérito de sus obras ${ }^{76}$. Es la última función que incluya La escuela de la amistad que hemos detectado por los años de la Ilustración.

La representación tuvo lugar el martes 26 de agosto de 1834. En esta ocasión fue montada en otro de los locales teatrales públicos madrileños, el Teatro del Príncipe, lugar en el que no había vuelto a ser presentada ante sus espectadores desde el anterior siglo XVIII (allí pudo ser contemplada por el público entre los días 25 de abril y 5 de mayo de 1796, como explicamos con anterioridad) y desde principios del siglo XIX (1809). Permaneció en cartel una única jornada. El ya citado día 26 de agosto. El Diario de Avisos de Madrid de esta fecha (p. 218) describe la función de la siguiente forma:

En el del Principe á las ocho de la noche: El filósofo enamorado ó La escuela de la amistad, comedia de carácter en tres actos, compuesta por D. Juan Pablo Forner, magistrado español, bien conocido entre los amantes de las buenas letras por el mérito de sus obras. En seguida se ejecutará baile nacional; terminándose la función con el gracioso sainete titulado Tercera parte del soldado fanfarrón. Actores en la comedia: Sras. M. Diez, Bravo y D. Pinto. Sres. Tamayo, G. Perez, Galindo, Cubas \&c. Id. en el sainete: Sras. Castillo y Martines. Sres. F. del Rio, Tamayo, S. Diez \&c.

Según ello, la comedia del emeritense se escenificó acompañada de un «baile nacional" y "el gracioso sainete titulado Tercera parte del soldado fanfarrón", complementos estos que se utilizarían como fin de fiesta.

Los componentes de la compañía que se encargaron del montaje son, como hemos comprobado, citados nominalmente en el Diario de Avisos.

La función del 26 de agosto de 1834 estuvo precedida por otra, ofrecida el día anterior, el 25 de agosto, que es presentada así en el Diario de Avisos: "Teatro. En el del Principe á las ocho de la noche: Se dará principio con una sinfonia: en seguida la última representacion por ahora de Edipo, tragedia original en cinco actos de don Francisco Martinez de la Rosa. Actores: Sra. Rodriguez. Sres. C. Latorre, Mate, P. Lopes \&c. // Nota. La disposicion particular de la escena para esta tragedia no permite agregarla los intermedios de baile y sainete que se acostumbran en las demas funciones ${ }^{77}$. A ella la sucedió la siguiente, representada el día 27 de agosto:

En el del Principe á las ocho de la noche: Parisina d'Este, ópera nueva en tres actos, una de las mas aplaudidas del maestro Donizzetti ${ }^{78}$. En ella se presentará por primera vez á desempeñar la parte de primer tenor D. Manuel Ojeda Manti, á quien no puede menos de alentar la notoria ilustracion de este público, que juzgará sin

76. Diario de Avisos de Madrid, del martes 26 de agosto de 1834, p. 218.

77. Diario de Avisos de Madrid, del lunes 25 de agosto de 1834, p. 214.

78. Parisina d'Este fue una ópera de Gaetano Donizetti, escrita en tres actos y estrenada, en el Teatro florentino de la Pérgola, el día 17 de marzo de 1833. Su libreto fue obra de Felice Romani. 
duda con patriótica indulgencia el primer paso que en la arriesgada escena va á dar un joven artista español, recomendable, como todos saben, por sus circunstancias personales. Actores: Sras. Grisi y Serrano. Sres, Ojeda, Botelli, Rodriguez y coristas ${ }^{79}$.

Siguiendo la costumbre de los últimos años, los ejemplares del Diario de Avisos de Madrid que hemos consultado no ofrecen cifras de la recaudación de taquilla.

\section{CONCLUSIONES: FORNER, DRAMATURGO CLÁSICO, y PRINCIPAL, DE LA ILUSTRACIÓN}

Ante la claridad y contundencia de los datos que hemos ido ofreciendo en las páginas de la presente investigación, las conclusiones que pueden ofrecerse de la misma son claras, y relativa y consiguientemente evidentes.

Frente a la idea que muchas veces se ha proporcionado sobre la producción dramática del extremeño Juan Pablo Forner, de estar compuesta por textos mediocres, que no fueron muy del agrado de sus contemporáneos ni de los años posteriores al emeritense, el escritor dieciochesco debe ser objeto de una gran reivindicación, como reparación de su memoria y buena reputación como comediógrafo. Sus creaciones teatrales no carecen de la calidad que le han negado algunos de sus críticos, de sus tiempos y de los siglos posteriores -hasta casi llegar a nuestros días-, que se han dejado arrastrar por prejuicios surgidos en los años de la Ilustración y pergeñados por adversarios y enemigos, políticos y personales, de nuestro eximio intelectual y autor ilustrado. El público del momento, sus receptores más inmediatos y más alejados de sus tiempos concretos, de finales del siglo XVIII -como estudiamos en otro lugar ${ }^{80}$ y principios del XIX, hasta la conclusión del reinado de Fernando VII -que son los límites que impusimos a nuestro trabajo-, así lo supieron ver y reconocer.

Las comedias de Juan Pablo Forner fueron textos muy bien recibidos en los momentos en los que fueron ofrecidos al público asistente a los locales teatrales, tanto en los últimos años de la vida de nuestro extremeño -de los que nos ocupamos en otro trabajo- ${ }^{81}$ como, muerto ya el emeritense, entre los años 1800 y 1834 , y así lo prueban los días en los que permanecieron en cartel y los datos de la recaudación obtenida en cada una de esas fechas, según son recogidos en la prensa aparecida en el periodo. Lo comprobamos en las investigaciones que dedicamos, sobre estos extremos, a una de sus producciones hasta ahora poco conocidas,

79. Diario de Avisos de Madrid, del miércoles 27 de agosto de 1834, p. 222.

80. Jesús Cañas Murillo, "La escuela de la amistad o El Filósofo enamorado en la prensa española de la Ilustración: Estrenos y reposiciones en vida de Forner (1790-1797)», en curso de publicación.

81. Jesús Cañas Murillo, "La escuela de la amistad o El Filósofo enamorado en la prensa española de la Ilustración: Estrenos y reposiciones en vida de Forner (1790-1797)", ya citado. 
Los aduladores ${ }^{82}$. Lo hemos comprobado, igualmente, a través de las páginas de esta investigación que estamos concluyendo y que hemos centrado en otra de sus composiciones, La escuela de la amistad o El Filósofo enamorado.

Los espectáculos que se ofrecieron, en los finales del siglo XVIII -en otro artículo analizados ${ }^{83}$ e inicios del XIX, en los que se incluía como base El Filósofo enamorado, y los datos de sus constantes y continuas reposiciones, así como de las respetables recaudaciones de taquilla que muchos de ellos aportaron a sus promotores, llevan, igualmente, a conclusiones similares a las que estamos exponiendo. La pieza fue objeto de siete posibles montajes en las postrimerías del siglo XVIII, como comprobamos en otro trabajo ${ }^{84}$, y de diecisiete reposiciones en los primeros años del XIX hasta 1834, algunas acaecidas dentro de un mismo año natural (en concreto, tres, en 1801; dos, en 1808 y en 1816). Es muestra del gran aprecio que dispensó el público, en su día, a La escuela de la amistad, obra que quedó convertida en un clásico de la escena, como reflejan los periódicos del momento, que citan reiteradas funciones suyas en el setecientos y en el ochocientos (veintidós documentadas por la prensa; una mencionada en una carta por Forner; y una más posible pero sin documentar, la de su supuesto primer estreno gaditano que pudo tener lugar entre 1792 y 1794), habidas en los años ¿1792-1794?, 1795, 1796, 1797, 1800, 1801, 1804, 1808, 1809, 1811, 1813, 1814, 1816, 1824, 1828, 1829, 1830 y 1834. Clásico de la escena, de igual modo, fue convertido también su autor, como lo prueban las constantes y abundantes citas con las tablas que le fueron habitualmente reservadas, por sucesivas compañías de cómicos, durante muchos de los años de la Ilustración, como también prueban los periódicos de ese tiempo ${ }^{85}$.

Nos hallamos, pues, en el momento perfecto, ante las nuevas evidencias que hemos venido aportando, para introducir cambios importantes en los juicios que muchas veces hemos podido leer en estudios críticos y en la historiografía literaria cuando se ocupan de nuestro emeritense. Juan Pablo Forner es uno de los insignes escritores e intelectuales de la Ilustración hispana, una de las figuras principales del siglo XVIII español, uno de los nombres que cualquier investigador imparcial debe valorar, también como dramaturgo, con mayor justicia de la que, tradicionalmente, se le ha concedido, y considerarlo, sin absurdas discusiones superfluas, un verdadero y destacable clásico hispano, digno de reconocimiento,

82. Cf. Cañas Murillo, Jesús. "Un texto teatral oculto de Juan Pablo Forner: La comedia de Los Aduladores". Lexis. Revista de Lingüística y Literatura, volumen XLIV, número 2 (diciembre de 2020), pp. 699-744; y "Los aduladores, de Juan Pablo Forner, comedia olvidada", en prensa en Homenaje a José Checa, Madrid: CSIC.

83. Cañas Murillo, Jesús. "La escuela de la amistad o El Filósofo enamorado en la prensa española de la Ilustración: Estrenos y reposiciones en vida de Forner (1790-1797)», citado.

84. Ibidem.

85. Cf. supra. 
respeto y admiración, para «los amantes de las buenas letras por el mérito de sus obras ${ }^{86}$, incluidas sus producciones teatrales.

Cáceres, 9 de noviembre de 2020, año de la pandemia.

\section{APÉNDICE \\ Representaciones de El Filósofo en la pRENSA EsPaÑola de la Ilustración (1800- 1834): DOCUMENTACIÓN ${ }^{87}$}

- $\quad$ Diario de Madrid, del martes 14 de enero de 1800, p. 56.

- Diario de Madrid, del miércoles 15 de enero de 1800, p. 60.

- Diario de Madrid, del jueves 16 de enero de 1800, p. 64.

- Diario de Madrid, del viernes 17 de enero de 1800, p. 68.

- Diario de Madrid, del sábado 18 de enero de 1800, p. 72.

- Diario de Madrid, del domingo 19 de enero de 1800, p. 76.

- $\quad$ Diario de Madrid, del lunes 20 de enero de 1800, p. 80.

- Diario de Madrid, del martes 21 de enero de 1800, p. 84.

- Diario de Madrid, del miércoles 22 de enero de 1800, p. 88.

- Diario de Madrid, del jueves 23 de enero de 1800, p. 92.

- Diario de Madrid, del viernes 24 de enero de 1800, p. 92.

- Diario de Madrid, del miércoles 12 de agosto de 1801, p. 924.

- Diario de Madrid, del jueves 13 de agosto de 1801, p. 928.

- Diario de Madrid, del viernes 14 de agosto de 1801, p. 932.

- Diario de Madrid, del sábado 15 de agosto de 1801, p. 936.

- Diario de Madrid, del domingo 16 de agosto de 1801, p. 940.

- Diario de Madrid, del lunes 17 de agosto de 1801, p. 1076.

- Diario de Madrid, del sábado 19 de septiembre de 1801, p. 1076.

- Diario de Madrid, del domingo 20 de septiembre de 1801, p. 1080.

- Diario de Madrid, del lunes 21 de septiembre de 1801, p. 1084.

- Diario de Madrid, del domingo 8 de noviembre de 1801, p. 1280.

- Diario de Madrid, del lunes 9 de noviembre de 1801, p. 1284.

- $\quad$ Diario de Madrid, del martes 10 de noviembre de 1801, p. 1288.

86. Diario de Avisos de Madrid, del martes 26 de agosto de 1834, p. 218.

87. Incluimos en este apéndice una relación de ejemplares de periódicos de la época que incluyen en sus páginas referencias a representaciones de El Filósofo enamorado, y que han servido como base para realizar nuestra investigación y documentar los datos aportados y las conclusiones en ellos fundamentadas. En el listado seguimos el orden cronológico de publicación. Algunos de tales ejemplares no contienen datos directos sobre representaciones de El Filósofo, sino noticias indirectas, pero relacionadas con la comedia, como recaudaciones obtenidas en taquilla, texto que le precedió o le sucedió en cartel, referencias a prohibiciones de la misma por motivos de censura eclesiástica, anuncios de estrenos próximos de la pieza o enumeraciones de los cómicos que formaban la compañía encargada del montaje de esta. 
- Diario de Madrid, del miércoles 11 de noviembre de 1801, p. 1292.

- Diario de Madrid, del jueves 12 de noviembre de 1801, p. 1296.

- $\quad$ Diario de Madrid, del miércoles 18 de abril de 1804, p. 436.

- Diario de Madrid, del jueves 19 de abril de 1804, p. 440.

- Diario de Madrid, del viernes 20 de abril de 1804, p. 444.

- Diario de Madrid, del sábado 21 de abril de 1804, p. 448.

- Diario de Madrid, del domingo 22 de abril de 1804, p. 454.

- Diario de Madrid, del lunes 23 de abril de 1804, p. 459.

- Diario de Madrid, del martes 24 de abril de 1804, p. 464.

- Diario de Madrid, del viernes 29 de enero de 1808, p. 128.

- Diario de Madrid, del sábado 30 de enero de 1808, p. 132.

- Diario de Madrid, del domingo 31 de enero de 1808, p. 136.

- Diario de Madrid, del sábado 26 de marzo de 1808, p. 136.

- Diario de Madrid, del lunes 1 de febrero de 1808, p. 140.

- Diario de Madrid, del martes 2 de febrero de 1808, p. 144.

- Diario de Madrid, del miércoles 3 de febrero de 1808, p. 148.

- Memorial Literario o Biblioteca Periódica de Ciencias, Literatura y Artes, n. ${ }^{\circ}$ 9. ${ }^{\circ}$, día 30 de marzo de 1808, trimestre primero, pp. 228-229.

- Minerva. El Revisor General. Obra periódica. Continua XL. Trimestre Noveno. Miscelánea. Crítica. Tomo VIII, 1807, n. ${ }^{\circ}$ 11, febrero 5 de 1808, p. 224.

- Minerva Obra Periódica. El Misántropo y El Revisor, o Revista de las Costumbres, en que se forma un quadro verdadero de las de este siglo, y se comprehende la Revista Literaria o Idea del actual estado de las Ciencias. Miscelánea. Crítica. Tomo IX. 1808. N. ' 27, abril 1 de 1808, p. 48.

- Diario de Madrid, del miércoles 23 de marzo de 1808, p. 372.

- Diario de Madrid, del jueves 24 de marzo de 1808, p. 376.

- Diario de Madrid, del viernes 25 de marzo de 1808, p. 380.

- Diario de Madrid, del sábado 26 de marzo de 1808, p. 384.

- Diario de Madrid, del domingo 27 de marzo de 1808, p. 388.

- Diario de Madrid, del lunes 28 de marzo de 1808, p. 392.

- Diario de Madrid, del martes 29 de marzo de 1808, p. 396.

- Diario de Madrid, del viernes 15 de septiembre de 1809, p. 308.

- Diario de Madrid, del domingo 17 de septiembre de 1809, p. 316.

- Diario de Madrid, del lunes 18 de septiembre de 1809, p. 320.

- Diario de Madrid, del miércoles 20 de septiembre de 1809, p. 328.

- Diario de Palma, del jueves 19 de diciembre de 1811, p. 452.

- Diario de Palma, del sábado 21 de diciembre de 1811, p. 460.

- Diario de Palma, del domingo 22 de diciembre de 1811, p. 464.

- El Conciso. N. 21, domingo 21 de febrero de 1813. Año 6. ${ }^{\circ}$ de la gloriosa lucha del pueblo español contra la tiranía, p. 7.

- El Conciso. N. 22, lunes 22 de febrero de 1813. Año $6 .^{\circ}$ de la gloriosa lucha del pueblo español contra la tiranía, p. 7. 
- El Conciso. N. 23, martes 23 de febrero de 1813. Año 6. ${ }^{\circ}$ de la gloriosa lucha del pueblo español contra la tiranía, p. 7.

- Diario de Madrid, del domingo 9 de octubre de 1814, p. 396.

- Diario de Madrid, del lunes 10 de octubre de 1814, p. 400.

- Diario de Madrid, del martes 11 de octubre de 1814, p. 404.

- Diario de Madrid, del miércoles 12 de octubre de 1814, p. 408.

- Diario de Madrid, del jueves 13 de octubre de 1814, p. 412.

- $\quad$ Diario de Madrid, del viernes 14 de octubre de 1814, p. 416.

- $\quad$ Diario de Madrid, del viernes 17 de octubre de 1814, p. 428.

- Diario de Madrid, del domingo 16 de junio de 1816, p. 748.

- Diario de Madrid, del lunes 17 de junio de 1816, p. 752.

- Diario de Madrid, del martes 18 de junio de 1816, p. 756.

- $\quad$ Diario de Madrid, del miércoles 19 de junio de 1816, p. 760.

- Diario de Madrid, del jueves 20 de junio de 1816, p. 764.

- Diario de Madrid, del miércoles 5 de mayo de 1824, p. 4.

- Diario de Madrid, del jueves 6 de mayo de 1824, p. 4.

- Diario de Madrid, del viernes 7 de mayo de 1824, p. 4.

- Diario de Madrid, del sábado 8 de mayo de 1824, p. 8.

- $\quad$ Diario de Madrid, del domingo 9 de mayo de 1824, p. 4.

- Diario de Avisos de Madrid. Sábado 14 de junio de 1828, p. 664.

- Diario de Avisos de Madrid. Domingo 15 de junio de 1828, p. 668.

- Diario de Avisos de Madrid. Lunes 16 de junio de 1828, p. 672.

- Diario de Avisos de Madrid. Martes 17 de junio de 1828, p. 676.

- Diario de Avisos de Madrid. Miércoles 18 de junio de 1828, p. 680.

- Diario de Avisos de Madrid. Jueves 19 de junio de 1828, p. 684.

- Diario de Avisos de Madrid. Viernes 20 de junio de 1828, p. 688.

- Gaceta de Bayona. Periódico Político, Literario e Industrial. N. ${ }^{\circ}$ 52, lunes 30 de marzo de 1829, p. 3.

- Diario de Avisos de Madrid. Domingo 5 de septiembre de 1830, p. 1000.

- Diario de Avisos de Madrid. Lunes 6 de septiembre de 1830, p. 1004.

- Diario de Avisos de Madrid. Martes 7 de septiembre de 1830, p. 1008.

- Diario de Avisos de Madrid. Miércoles 8 de septiembre de 1830, p. 1012.

- Diario de Avisos de Madrid. Jueves 9 de septiembre de 1830, p. 1016.

- Diario de Avisos de Madrid. Viernes 1 de octubre de 1830, p. 1104.

- $\quad$ Diario de Avisos de Madrid. Sábado 2 de octubre de 1830, p. 1108.

- Diario de Avisos de Madrid. Domingo 3 de octubre de 1830, p. 1112.

- Diario de Avisos de Madrid. Lunes 25 de agosto de 1834, p. 214.

- Diario de Avisos de Madrid. Martes 26 de agosto de 1834, p. 218.

- Diario de Avisos de Madrid. Miércoles 27 de agosto de 1834, p. 222. 